\title{
AKTIVITAS PROMOSI DALAM MENINGKATKAN DANA PIHAK KETIGA PADA PT. BANK PERKREDITAN RAKYAT (BPR) BATANG KAPAS PESISIR SELATAN
}

\author{
Rara Riezka Hidayati, Doni Marlius \\ Akademi Keuangan dan Perbankan Padang \\ donimarlius@akbpstie.ac.id
}

\begin{abstract}
The decision to save and deposit the deposits are the actions that are directly involved in the business of obtaining, determining the products and services including the decision making process of saving and depositing deposits and following these actions the purpose of this study is to determine the promotion activities in increasing third party funds at PT. Bank Perkreditan Rakyat (BPR) Batang Kapas Pesisir Selatan. The research method used is descriptive skin method that is collecting information about promotion activity in increasing third party fund. The results of research To conduct promotional activities in increasing third party funds PT. Bank Perkreditan Rakyat (BPR) Batang Kapas Pesisir Selatan has promoted sales promotion and personal selling such as giving gift to old customers in order to avoid customers moving to other banks. Promotional activities undertaken by PT. Bank Perkreditan Rakyat (BPR) Batang Kapas Pesisir Selatan. Only targeted to certain people or people only, on savings and time deposits. From the results of research that has been done PT. Bank Perkreditan Rakyat (BPR) Batang Kapas Pesisir Selatan have not fully implemented promotional activities such as tami and puro nagari savings products.
\end{abstract}

Keywords: promotion, third party funds.

\section{PENDAHULUAN}

Dalam era globalisasi perekonomian suatu negara tidak terlepas dari peranan perbankan karena sudah menjadi landasan dalam mengahadapi perkembangan ekonomi di zaman yang semakin maju seperti zaman sekarang yang berguna untuk meningkatkan pertumbuhan ekonomi masyarakat banyak dan menciptakan perekonomian yang stabil melalui bank-bank yang ada di Indonesia.

Bank merupakan suatu lembaga keuangan yang berfungsi menghimpun dana dari masyarakat dan kemudian menyalurkannya kembali kepada masyarakat banyak dalam bentuk kredit dan menurut (Undang-undang RI Nomor 10, 1998 Tentang Perbankan) Bank adalah badan usaha yang menghimpun dana dari masyarakat dalam bentuk simpanan dan menyalurkannya kepada masyarakat dalam bentuk kredit dan atau bentuk-bentuk lainnya dalam rangka meningkatkan taraf hidup rakyat banyak. Salah satu fungsi utama bank ialah sebagai lembaga perantara (intermediary) antara 
masyarakat yang membutuhkan dana, dan keuntungan bank diperoleh dari selisih harga jual dan harga beli dana tersebut dikurangi dengan biaya operasional.Menurut Rahmadhani, (2011) Bank secara sederhana dapat diartikan sebagai lembaga keuangan yang kegiatan utamanya adalah menghimpun dana dari masyarakat dan menyalurkannya kembali dana tersebut ke masyarakat serta memberikan jasa bank lainnya.

Bank dibagi menjadi dua yaitu bank umum dan Bank Perkreditan Rakyat (BPR). Bank Umum adalah bank yang melaksanakan kegiatan usaha secara konvensional dan atau berdasarkan prinsip syariah, yang dalam kegiatannya memberikan jasa dalam lalu lintas pembayaran, dan Bank Perkreditan Rakyat (BPR) adalah bank yang melaksanakan kegiatan usaha secara konvensional dan atau berdasarkan prinsip syariah, tetapi tidak memberikan jasa dalam lalu lintas pembayaran. Usaha BPR menghimpun dana dari masyarakat dalam bentuk simpanan berupa deposito berjangka, tabungan, dan/atau bentuk lainnya yang dipersamakan dengan itu.

Menurut Herri, (2008) BPR adalah salah satu bentuk lembaga keuangan mikro di Indonesia yang telah memiliki akar dalam sosial ekonomi masyarakat pedesaan Indonesia. BPR sebagai salah satu lembaga perbankan juga mempunyai peranan yang cukup penting dalam menunjang perekonomian Indonesia. Salah satu peran BPR adalah membantu masyarakat yang sulit memiliki akses peminjaman dana ke bank umum, sehingga masyarakat tidak perlu meminjam uang kepada rentenir. BPR juga berperan serta dalam menunjang perkembangan Usaha Kecil Menengah (UKM) di Indonesia yang menjadi salah satu sektor usaha terbesar yang ada di Indonesia yang membantu pemerintah dalam penciptaan lapangan pekerjaan. Peran BPR disini adalah membantu perkembangan UKM melalui peminjaman modal yang dihimpun dari dana masyarakat. Sebagai lembaga yang dipercaya masyarakat dalam menghimpun dan menyalurkan dana dari dan ke masyarakat, maka BPR harus meningkatkan kinerja keuangan serta kesehatannya dari waktu ke waktu. Dengan kinerja keuangan yang baik, maka kepercayaan masyarakat kepada BPR sebagai lembaga keuangan penghimpun dan penyalur dana juga akan semakin tinggi.

Situasi perbankan yang demikian, PT Bank Perkreditan Rakyat (BPR) ikut berlomba mengejar para nasabahnya dengan cara melakukan promosi guna untuk meningkatkan jumlah nasabahnya. Promosi merupakan bagian dari rangkaian kegiatan pemasaran, dan aktivitas promosi adalah bagaimana cara mengkomunikasikan suatu pesan (produk) kepada publik. Aktivitas tersebut menyangkut sejumlah aspek yang terkait dengan produk salah satu aktivitas promosi adalah melalui event, bank memanfaatkan event sebagai mediator pesan perusahaan dalam mencapai sasaran. Salah satu alat promosi yang kini semakin digemari banyak bank adalah promosi tabungan, selain mudah, juga tidak membutuhkan biaya yang besar.

Menurut Denny, (2013) promosi adalah jenis komunikasi yang memberi penjelasan yang meyakinkan calon konsumen tentang barang dan jasa. Hal ini bertujuan untuk perhatian, mendidik, mengingatkan, dan meyakinkan calon konsumen.

Menurut Buchari Alma (2006:179) Promosi adalah sejenis komunikasi yang memberi penjelasan dan meyakinkan calon konsumen mengenai barang dan jasa de ngan tujuan untuk memperoleh perhatian, mendidik, mengingatkan dan meyakinkan calon konsumen. 
Promosi dilakukan untuk meningkatkan dana yang dapat terkumpul dari masyarakat yang dikenal dengan tabungan masyarakat, yaitu giro tabungan dan deposito, tetapi pada PT. Bank Perkreditan Rakyat Batang Kapas Pesisir Selatan produk tabungan dan deposito masyarakat memiliki peran penting dalam pertumbuhan ekonomi yang berfungsi sebagai modal dan investasi. Dana tersebut akan disalurkan kembali kepada masyarakat dalam bentuk kredit, sehingga tingkat tabungan sangat mempengaruhi tingkat penyaluran kredit kepada masyarakat dengan hubungan yang positif. Semakin besar jumlah tabungan yang dikumpulkan perbankan dari masyarakat maka akan semakin besar tingkat penyaluran kredit sesuai dengan fungsi dan kegiatannya maka pengelolaan jasa bank yang paling utama adalah bagaimana mengelola kegiatan menghimpun dana.

Upaya menghimpun dana ini dapat dilakukan dengan menawarkan produk simpanan yang ada di PT. Bank Perkreditan Rakyat (BPR) Batang Kapas Pesisir Selatan seperti tabungan dan deposito. Bagi masyarakat batang kapas tabungan merupakan produk yang paling diminati di PT. Bank Perkreditan Rakyat (BPR) Batang Kapas Pesisir Selatan karena penarikkan nya dapat dilakukan sewaktu-waktu.

PT. Bank Perkreditan Rakyat (BPR) Batang Kapas Pesisir Selatan menyelenggarakan sistem "simpanan bajapuik" (simpanan di jemput) artinya, petugas bank datang sendiri kepada nasabah untuk menjemput simpanan yang dilakukan per hari, per minggu atau per bulan tergantung permintaan nasabah itu sendiri. Sasaran utama dari kegiatan promosi ini dilakukan untuk menarik minat nasabah guna meningkatkan jumlah tabungan untuk disalurkan kembali kepada masyarakat batang kapas atau masyarakat yang membutuhkan.

Berikut ini data laporan tabungan dan deposito PT. Bank Perkreditan Rakyat (BPR) Batang Kapas Pesisir Selatan Periode 2013-2017 sebagai berikut :

\section{Tabel 1}

Data Jumlah Rekening Tabungan dan Deposito PT. Bank Perkreditan Rakyat (BPR) Batang Kapas Pesisir Selatan Periode 2013-2017

\begin{tabular}{ccc}
\hline Tahun & Jumlah rekening tabungan & Jumlah rekening deposito \\
\hline 2013 & 7.491 & 218 \\
2014 & 7.987 & 214 \\
2015 & 8.619 & 243 \\
2016 & 8.980 & 292 \\
2017 & 9.424 & 316 \\
\hline
\end{tabular}

Sumber: PT. Bank Perkreditan Rakyat (BPR) Batang Kapas Pesisir selatan.

Berdasarkan tabel diatas dapat diuraikan perkembangan jumlah nasabah tabungan dan deposito PT. Bank Perkreditan Rakyat (BPR) Batang Kapas Pesisir selatan pada tahun 2013 jumlah rekening tabungan sebesar 7.491 orang dengan jumlah rekening deposito sebesar 218 orang, pada tahun 2014 jumlah rekenig tabungan 7.987 orang dengan jumlah rekening deposito 214 orang, pada tahun 2015 jumlah rekening tabungan sebesar 8.619 orang dengan jumlah rekening deposito sebesar 243 orang, pada 
tahun 2016 jumlah rekening tabungan sebesar 8.980 orang dengan jumlah rekening deposito 292 orang, pada tahun 2017 jumlah rekening tabungan sebesar 9.424 orang dengan jumlah rekening deposito 316 orang. Tabungan pada PT. Bank Perkreditan Rakyat (BPR) Batang Kapas Pesisir Selatan semakin meningkat pada tahun dari tahun ketahun, tetapi berbeda halnya dengan produk deposito yang mengalami penurunan pada tahun 2014 dan untuk tahun 2015 sampai dengan tahun 2017 mengalami peningkatan jumlah nasabah deposito.

Berdasarkan uraian diatas penulis tertarik untuk melakukan penelitian dalam bentuk Tugas Akhir yang berjudul "Aktivitas Promosi Dalam Meningkatkan Dana Pihak Ketiga PT. Bank Perkreditan Rakyat (BPR) Batang Kapas Pesisir Selatan"

\section{METODE PENELITIAN}

Dalam pengumpulan data dan bahan untuk melakukan penelitian ini digunakan metode-metode pengumpulan data dan metode analisa data, sebagai berikut:

\section{Metode Pengumpulan Data}

Metode pengumpulan data adalah teknik atau cara yang dilakukan oleh peneliti untuk mengumpulkan data. Pengumpulan data dilakukan untuk memperoleh informasi yang dibutuhkan dengan cara

Observasi, yaitu penulis melakukan pengamatan penelitian untuk mendapatkan gambaran yang tepat mengenai subjek penelitian. Dalam penelitian ini yang menjadi penelitian adalah PT. Bank Perkreditan Rakyat (BPR) Batang Kapas Pesisir Selatan. Dokumentasi merupakan cacatan peristiwa yang berlalu, dokumentasi ini bisa berbentuk tulisan, gambar, dan lain-lain.

\section{Metode Analisa Data}

Di dalam menganalisa data, penulis menggunakan analisa data Kualitatif. Metode analisa data kualitatif ini digunakan sebagai metode penelitian yang menjelaskan secara deskriptif yaitu dengan menguraikan data secara sistematis dari aktivitas promosi yang dilakukan oleh PT. Bank Perkreditan Rakyat (BPR) Batang Kapas Pesisir Selatan.

\section{HASIL DAN PEMBAHASAN}

Menurut Metia, (2014) bank adalah badan usaha yang menghimpun dana dari masyarakat dalam bentuk simpanan dan menyalurkannya kepada masyarakat dalam bentuk kredit dan atau bentuk-bentuk lainnya dalam rangka meningkatkan taraf hidup rakyat banyak". Sedangkan menurut Pebriani, (2017) bank adalah badan usaha yang menghimpun dana dari masyarakat dalam bentuk simpanan dan menyalurkan kemasyarakat dalam rangka meningkatkan taraf hidup orang banyak.

\section{Jenis-jenis, Bentuk Hukum Dan Kegiatan Usaha Bank}

Menurut Kusnandar, (2013) jenisnya bank dibed akan menjadi 2 terdiri dari Bank umum, dan Bank Perkreditan Rakyat (BPR), mempunyai fungsi yang sama yaitu sebagai penghimpun dan penyalur dana masyarakat. Dalam hal ini menandakan bahwa bank sangatlah penting dalam pembangunan nasional karena fungsi bank dalam Pasal 1 
angka 2 UU perbankan mendefinisikan fungsi bank adalah badan usaha yang menghimpun dana dari masyarakat dalam bentuk simpanan dan menyalurkannya kepada masyarakat dalam bentuk kredit dan atau bentuk-bentuk lainnya dalam rangka meningkatkan taraf hidup rakyat banyak.

\section{Dana Pihak Ketiga}

Dana pihak ketiga adalah dana yang berasal dari masyarakat, baik perorangan maupun badan usaha, yang diperoleh bank dengan menggunakan berbagai instrumen produk simpanan yang dimiliki oleh bank (Sukma, 2013). Menurut (Dendawijaya 2009:49) mengungkapkan dana-dana pihak ketiga yang dihimpun dari masyarakat merupakan sumber dana terbesar yang paling diandalkan oleh bank (mencapai 80\%90\% dari seluruh dana yang dikelola oleh bank).

Sedangkan menurut Susan, (2014) dana pihak ketiga adalah simpanan dana dari nasabah kepada pihak Bank yang terdiri dari giro, tabungan, dan simpanan berjangka (deposito). Adapun menurut Delsy, (2014)Dana Pihak Ketiga adalah dana yang dihimpun dari masyarakat berupa tabungan, deposito dan giro. Dana yang dihimpun dari masyarakat digunakan oleh bank untuk melakukan ekspansi kredit maupun investasi. DPK merupakan hal yang penting bagi bank karena dengan semakin besar dana yang dihimpun maka dapat memperbesar profitabilitas bank melalui selisih bunga kredit dan bunga simpanan.

\section{Pengertian Tabungan}

Menurut Ika, (2015) adalah Tabungan adalah simpanan pihak ketiga pada bank yang penarikannya hanya dapat dilakukan menurut syarat-syarat tertentu yang disepakati, tetapi tidak dapat ditarik dengan cek, bilyet giro dan atau alat lainnya yang dipersamakan dengan itu. Menurut Vera, (2015) Tabungan merupakan bagian dari pendapatan yang tidak di konsumsi atau sama dengan jumlah konsumsi, jadi disimpan dan akan digunakan di masa yang akan datang.

\section{Pengertian Deposito}

Menurut Melnia, (2015) deposito adalah simpanan pihak ketiga kepada bank yang penarikannya dapat dilakukan dengan jangka waktu tertentu menurut perjanjian antara pihak ketiga dengan bank atau berdasarkan perjanjan deposan dengan pihak bank.Deposito merupakan salah satu tempat bagi nasabah untuk melakukan investasi dalam bentuk surat-surat berharga. Pemilik deposito di sebut deposan. Kepada setiap deposan akan diberikan imbalan bunga atas depositonya. Bagi bank, bunga yang di berikan kepada para deposan merupakan bunga yang tertinggi, jika dibandingkan dengan simpanan giro atau tabungan, sehingga deposito oleh sebagian bank dianggap sebagai dana mahal. Keuntungan bagi bank dengan menghimpun dana lewat deposito adalah uang yang tersimpan relative lebih lama, mengingat deposito memiliki jangka waktu yang relative panjang dan frekuensi penarikan juga jarang. Dengan demikian, bank dapat dengan leluasa untuk menggunakan kembali dana tersebut untuk keperluan penyalur kredit (Nurfaizah, 2013). 


\section{Pemasaran}

Seiring berkembangnya kemajuan ilmu pengetahuan dan teknologi, gaya hidup manusia terutama mengenai pemilihan makanan yang akan dikonsumsi akan semakin beragam. Hal ini dikarenakan lahirnya segala macam jenis produk dari ide-ide yang kreatif. Dengan demikian perusahaan dalam menjalankan usahanya perlu mengenmbangkan strategi pemasarannya, agar mampu bertahan dalam persaingan usaha yang beragam. Pemasaran merupakan salah satu aspek penting dalam kegiatan bisnis. Perusahaan dalam menjalankan usahanya perlu mengembangkan strategi pemasarannya, agar mampu bertahan dalam persaingan usaha yang beraneka ragam, yang berdampak pada persaingan usaha yang sejenis (Adhaghassani, 2016).

Menurut Irawan, (2014) Dimana pemasaran dapat diartikan sebagai sebuah proses sosial dan manajerial dari individu atau kelompok pembeli dalam mendapatkan apa yang mereka butuhkan dan inginkan melalui penciptaan, penawaran dan pertukaran produk yang bernilai dengan individu atau kelompok lainnya. Kegiatan pemasaran jasa harus dapat mendekatkan konsumen, pelanggan, mengkaji peluang-peluang pasar, menetapkan posisi jasa segmen pasar dan pasar sasaran atas dasar kebutuhan jasa tersebut serta merumuskan bauran pemasaran (marketingmix), yang meliputi mutu dan deversifikasi jasa, harga atau tarif dari kegiatan promosi dan strategi penyampaian jasa tersebut. Marketing mix (Bauran Pemasaran Jasa) Salah satu strategi yang berhubungan dengan kegiatan pemasaran perusahaan :

a. Product (Produk)

Produk yaitu segala sesuatu yang ditawarkan kepada pangsa pasar agar diperhatikan, diminta, dipakai, atau dikonsumsi sehingga memuaskan kebutuhan atau keinginan konsumen. Istilah produk mempunyai bermacammacam arti dan makna. Produk adalah segala sesuatu yang dapat ditawarkan ke pasar untuk menarik perhatian, pembelian atau dikonsumsi yang dapat memuaskan keinginan atau kebutuhan (Kaharu \& Budiarti, 2016)

b. Price (Harga)

Harga merupakan salah satu variabel penting dalam pemasaran, dimana harga dapat mempengaruhi konsumen dalam mengambil keputusan untuk membeli suatu produk, karena berbagai alasan. Alasan ekonomis akan menunjukkan harga yang rendah atau harga terlalu berkompetisi merupakan salah satu pemicu penting untuk meningkatkan kinerja pemasaran, tetapi alasan psikologis dapat menunjukkan bahwa harga justru merupakan indikator kualitas dan karena itu dirancang sebagai salah satu instrumen penjualan sekaligus sebagai instrument kompetisi yang menentukan (Mongi, Mananeke, \& Repi, 2013).

c. Promotion (Promosi)

Menurut (Febrianto, 2014) Promosi adalah kegiatan yang dilakukan perusahaan dengan tujuan utama untuk menginformasikan, membujuk, mempengaruhi, dan mengingatkan konsumen agar membeli produk yang 
dihasilkan. Strategi promosi (promotion strategi) memerlukan adversiting, sales promotion, personal selling, dan publicity keadaan sebuah program yang terkoordinasi untuk berkomunikasi dengan para pembeli dan pihak lainya yang mempengaruhi keputusan pembelian. Aktifitas promosi mempunyai pengaruh penting atas penjualan produk dicapai oleh suatu usaha. Pengelolaan yang efektif atas sumber daya yang mahal tersebut adalah potensial untuk mencapai hasil imbalan optimal dari pengeluaran promosi. Sebenarnya tujuan dari promosi adalah mempengaruhi prilaku. Beberapa faktor yang harus diperhatikan dalam menyusun strategi bauran promosi antara lain :

1) Faktor Produk, pada produk yang dalam kategori industri dan bersifat teknis bauran pemasaran yang baik adalah personal selling. Selain itu personal selling juga digunakan untuk produk dengan resiko pembeli tinggi, sedangkan pada produk yang dibeli dalam jumlah kecil dengan frekuensi tinggi maka strategi yang digunakan adalah iklan.

2) Faktor Pasar, pada faktor pasar yang diperhatikan adalah product life cycle. Pada tahap perkenalan maka iklan lebih mendominasi. Sedangkan pada masa kedewasaan dan penurunan dibutuhkan strategi iklan dan promosi.

3) Faktor Pelanggan, dilihat dari faktor pelanggan-pelanggan rumah tangga lebih baik menggunakan pendekatan iklan sedangkan jika pelanggan adalah industri maka personal selling lebih tepat. Dalam kaitannya dengan sasaran yang dituju terdapat dua strategi yang bisa digunakan, yaitu push strategy yang ditekankan untuk membeli langsung, dan pull strategy.

4) Faktor Anggaran, jika perusahaan memiliki dana promosi yang besar, maka peluangnya untuk menggunakan iklan yang bersifat nasional juga besar.Sebaiknya bila dana terbatas, maka dapat memilih personal selling, promosi penjualan atau iklan bersama di wilayah local atau regional.

5) Faktor Bauran Pemasaran, pada bauran pemasaran sangat menentukan pilihan media promosi baik iklan, personal selling, maupun publisitas.

\section{d. Place (Saluran Distribusi)}

Menurut (Radix, 2010) Menyatakan bahwa "Saluran distribusi terdiri dari seperangkat lembaga yang melakukan segala kegiatan (Fungsi) yang digunakan untuk menyalurkan produk dan status pemiliknya dari produsen ke konsumen". Dari definisi diatas dapat diartikan bahwa saluran distribusi suatu barang adalah keseluruhan kegiatan atau fungsi untuk memindahkan produk disertai dengan hak pemiliknya dari produsen ke konsumen akhir atau pemakai industri. Distribusi berkaitan dengan kemudahan memperoleh produk di pasar dan tersedia saat konsumen mencarinya. Distribusi memperlihatkan berbagai kegiatan yang dilakukan perusahaan untuk menjadikan produk atau jasa diperoleh dan tersedia bagi konsumen sasaran.

e. People (Partisipan)

Orang berfungsi sebagai penyedia jasa sangat mempengaruhi kualitas jasa yang diberikan. Keputusan dalam faktor ini berarti sehubungan dengan seleksi, 
pelatihan, motivasi, dan manajemen sumber daya manusia, Untuk mencapai kualitas yang terbaik, pegawai harus dilatih untuk menyadari pentingnya pekerjaan mereka. Yaitu memberikan konsumen kepuasan dalam memenuhi kebutuhannya. Pentingnya sumber daya manusia dalam pemasaran jasa berkaitan erat dengan pemasaran. Terdapat dua elemen partisipan, Services people. Memegang jabatan ganda mengadakan jasa dan menjual jasa tersebut. Melalui pelayanan yang baik, cepat, ramah, teliti dan kesetiaan pelanggan terhadap perusahaan yang akhirnya akan meningkatkan nama baik perusahaan. Faktor lain yang mempengaruhi adalah hubungan yang ada diantara para pelanggan. Pelanggan dapat memberikan persepsi kepada konsumen lain, tentang kualitas jasa yang pernah didapatnya dari perusahaan. Keberhasilan manajemen dari sumber daya manusia. Pemasaran internal semakin diakui perusahaan jasa dalam menentukan suksesnya pemasaran ke pelanggan eksternal (Yuniati, 2015)

f. Process (Proses)

(Senaen \& Tumbuan, 2015) menyatakan bahwa proses ialah semua prosedur aktual, mekanisme dan aliran aktivitas yang digunakan untuk menyampaikan jasa.

g. Physical Evidence (Lingkungan Fisik)

Menurut (Yuniati, 2015) Bukti fisik merupakan lingkungan fisik tempat jasa diciptakan dan langsung berinteraksi dengan konsumen. Ada dua jenis bukti fisik, sebagai berikut:

1) Bukti penting (essential evidence), merupakan keputusan-keputusan yang dibuat oleh pemberi jasa mengenai desain dan tata letak (layout)dari gedung, ruang, dan lain-lain.

2) Bukti pendukung (peripheral evidence), merupakan nilai tambah yang apabila berdiri sendiri maka tidak akan berarti apa-apa.

Dengan demikian, hanya berfungsi sebagai pelengkap saja. Sekalipun demikian, peranannya sangat penting dalam proses produksi jasa. Sebagai contoh, tiket pesawat. Bukti fisik membantu pemasar untuk memposisikan perusahaannya di pasar dan memberikan dukungan nyata, terlebih yang berhubungan dengan lokasi.

\section{Promosi}

Promosi adalah jenis komunikasi yang memberi penjelasan yang meyakinkan calon konsumen tentang barang dan jasa. Hal ini bertujuan untuk perhatian, mendidik, mengingatkan, dan meyakinkan calon konsumen (Didik, 2013).

Menurut Denny, (2013) promosi merupakan fungsi komunikasi dari perusahaan yang bertanggung jawab menginformasikan, membujuk dan mengajak pembeli. 


\section{Jenis-jenis Promosi}

1. Iklan (Advertising)

Menurut (Sunardi, 2009) Kegiatan periklanan merupakan setiap bentuk presentasi yang berupa promosi, gagasan, barang atau jasa oleh sponsor yang telah ditentukan. Iklan dalam dunia pemasaran memiliki peranan yang sangat penting karena dalam periklanan memliki beberapa fungsi. menjelaskan periklanan memiliki beberapa fungsi berikut:

a. Informing, periklanan membuat calon konsumen menyadari tentang keberadaan sebuah merek baru, mendidik publik menyadari tentang fungsi-fungsi dan manfaat merek memberikan fasilitas dalam menbangun reputasi sebuah merek.

b. Persuading, periklanan berusaha membujuk calon konsumen untuk mencoba menggunakan atau membeli produk yang diiklankan.

c. Reminding, Iklan berusaha memengingatkan kepada publik untuk terus mengingat merek yang diiklankan sehingga public terus membeli merek tersebut.

d. Adding Value, Iklan selalu menampilkan kelebihan-kelebihan produk yang diiklankan dibandingkan pesaingnya, sehingga produk dapat memunculkan minat beli.

e. Assisting, periklanan dapat menbantu pemasar dalam memasarkan produknya.

\section{Promosi Penjualan (Sales Promotion)}

Promosi penjualan (sales promotion) merupakan kegiatan perusahaan untuk menjajakan produk yang dipasarkan sedemikian rupa, sehingga konsumen akan mudah melihatnya dan bahkan dengan cara penempatan dan pengaturan tertentu, maka produk tersebut akan menarik perhatian konsumen, promosi penjualan adalah insentif jangka pendek untuk mendorong pembelian atau penjualan dari sebuah produk atau jasa dengan tujuan, sebagai berikut:

(a) menarik para pembeli baru.

(b) memberi hadiah/penghargaan kepada konsumen-konsumen lama.

(c) meningkatkan daya pembelian ulang dari konsumen lama,

(d) menghindarkan konsumen berpindah ke merek lain.

(e) mempopulerkan merek atau meningkatkan loyalitas kepada merek.

(f) meningkatkan volume penjualan jangka pendek dalam rangka meningkatkan pangsa pasar jangka panjang (Ariyanti, 2014).

\section{Penjualan Perorangan (Personal Selling)}

Penjualan Perorangan (personal selling) merupakan penyajian secara lisan oleh perusahaan kepada satu atau beberapa calon pembeli dengan tujuan agar barang atau jasa yang ditawarkan dapat terjual, sedangkan mengemukakan bahwa penjualan perorangan merupakan kegiatan perusahaan untuk melakukan kontak langsung dengan para calon konsumen dan diharapkan akan terjadi suatu hubungan atau interaksi positif antara pengusaha dengan para konsumennya. Mengemukakan bahwa dalam personal selling terdapat kontak secara langsung antara penjual dan pembeli, sehingga dapat menciptakan komunikasi dua jalur antara pembeli dan penjual. Di samping menjelaskan atau memberitahukan tentang produk dan membujuk pembeli, 
personal selling juga menampung keluhan dan saran dari para pembeli sebagai umpan balik bagi perusahaan (Fuadati, 2014).

\section{Hubungan Masyarakat (Public Relations)}

Menurut (Sunardi, 2009) Hubungan masyarakat dan publisitas merupakan berbagai program dirancang untuk mempromosikan atau melindungi citra perusahaan atau masing-masing produknya. Hubungan masyarakat dan publisitas ini bertujuan untuk membangun reputasi perusahan terhadap publik sehingga dapat menghilangkan rumor, berita negatif, cerita dan peristiwa negatif.

\section{Pemasaran Langsung (Direct Marketing)}

Menurut(Rokhmi, 2014) Direct Marketing merupakan sistem pemasaran interaktif yang menggunakan berbagai media komunikasi untuk meningkatkan respon langsung yang sifatnya spesifik dan terukur. Metode-metode pemasaran langsung dapat melalui katalog, pos, telepon, TV, TV kabel, TV interaktif, mesin fax, internet dan lain-lain.

\section{Aktivitas promosi yang dilakukan PT. Bank Perk reditan Rakyat (BPR) Batang Kapas Pesisir Selatan}

Proses aktivitas promosi yang dilakukan oleh PT. Bank Perkreditan Rakyat (BPR) Batang Kapas Pesisir Selatan yaitu menentukan objek yang akan dilakukan promosi. Karena objek sangat penting untuk melihat serta memahami karakter dan kondisi dari calon nasabah tersebut, seperti yang dibawah ini aktivitas promosi yang dilakukan oleh PT. Bank Perkreditan Rakyat (BPR) Batang Kapas Pesisir Selatan :

1. Aktivitas promosi pada sekolah.

Proses aktivitas promosi pada sekolah ini lebih dominan pada Tami bajapuik yaitu tabungan yang dapat dijemput lansung ke rumah-rumah nasabah atau kesekolah. Proses pertama mendatangi sekolah yang akan di lakukan promosi. Dengan meminta izin terlebih dahulu kepada pihak sekolah. Dengan menyampaikan akan melakukan promosi tabungan kepada anak-anak sekolah, setelah mendapatkan izin dari pihak sekolah barulah dilakukan aktivitas promosi dengan memperkenalkan dan menyampaikan produk tabungan PT. Bank Perkreditan Rakyat (BPR) Batang Kapas Pesisir Selatan seperti :

a) Tami (Tabungan Kami)

Yaitu tabungan yang diperuntukkan untuk masyarakat baik dari penabung kecil sampai penabung besar, dengan ketentuan umum melampirkan kartu identitas/K TP, dan dengan setoran awal yang ringan minimal Rp. 25.000,dan adm Rp. 2.500,-/3bln.

b) Tami Bajapuik

Yaitu tabungan yang dijemput kerumah-rumah nasabah, tabungan bajapuik sangat memudahkan nasabah yang tidak bisa atau tidak sempat ke bank untuk menyetor tabungan, dengan ketentuan melampirkan kartu identitas/KTP dengan saldo awal minimal Rp. 10.000,- dan penyetoran berikutnya dengan saldo minimal Rp. 5.000,- serta dengan adm Rp. 2.500,-/3bln. 
c) Puro Nagari

Yaitu tabungan semua lapisan masyarakat. Dengan persyaratan pembukaan rekening melampirkan kartu identitas/KTP dan saldo awal minimal Rp. 25.000,- serta saldo setelah pengambilan minimal Rp. 25.000,-.

Tapi, PT. Bank Perkreditan Rakyat (BPR) Batang Kapas Pesisir Selatan sangat lebih mendetailkan penjelasan produk tabungan Tami Bajapuik. Dengan ditawarkan produk Tami Bajapuik ini, pihak sekolah akan lebih cepat tetarik serta lebih memudahkan calon nasabah tersebut untuk menabung. Karena, sasaran utama dari kegiatan promosi ini dilakukan untuk menarik minat nasabah guna meningkatkan jumlah tabungan pada PT. Bank Perkreditan Rakyat (BPR) Batang Kapas Pesisir Selatan.

2. Aktivitas promosi pada pasar

Proses aktivitas promosi pada pasar ini lebih dominan dengan Deposito Berjangka. Proses pertama yaitu dengan melihat bagaimana karakter dan keadaan kondisi di lingkungan pasar tersebut, karena itu adalah salah satu cara untuk menarik minat calon nasabah. Dengan memahami tersebut barulah melakukan promosi produk PT. Bank Perkreditan Rakyat (BPR) Batang Kapas Pesisir Selatan dengan memberikan brosur dan menjelaskan lebih detail tentang produk deposito berjangka PT. Bank Perkreditan Rakyat (BPR) Batang Kapas Pesisir Selatan. Seperti :

a. Deposito (SimpananBerjangka)

Yaitu simpanan yang penarikannya hanya dapat dilakukan dalam jangka waktu tertentu berdasarkan perjanjian nasabah dengan bank. Depositomemiliki keunggulan dari bank lain yang membantu masyarakat untuk mendapatkan tingkat suku bunga yang lebih tinggi. Deposito hanya bisa dicairkan pada saat jatuh tempo dan jika kita ingin mencairkan deposito tidak pada saat jatuh tempo maka kita akan dikenakan pinalty sesuai dengan ketentuan yang berlaku. Dan jika sudah jatuh tempo deposito belum juga dicairkan maka otomatis deposito tersebut di perpanjang.

Syarat dan cara deposito:

a. Melampirkan kartu identitas/KTP.

b. Mengisi formulir pendaftaran yang disiapkan oleh pihak bank .

c. Menandatangani formulir pendaftaran tersebut.

d. Mengisi slip setoran dan memberikan uang yang akan didepositokan.

e. Jika nasabah ingin mengambil uangnya, maka nasabah membawa bilyet deposito tersebut beserta materai @ 6000 (telah jatuh tempo).

Jenis-jenis deposito:
a) 1 (satu) bulan
b) 3 (tiga) bulan
c) 6 (enam) bulan
d) 12 (dua belas) bulan 
Jadi, seperti yang telah diteliti pada PT. Bank Perkreditan Rakyat (BPR) Batang Kapas Pesisir Selatan tersebut penggunaan deposito berjangka lebih banyak diminati oleh pedagang dan usaha kecil menengah (UKM) lainnya.

3. Aktivitas promosi pegawai dan pensiun

Proses aktivitas promosi untuk pegawai dan pensiun juga lebih mendominan dengan deposito berjangka. Karena calon nasabah tertarik dengan suku bunga yang lebih tinggi diberikan oleh PT. Bank Perkreditan Rakyat (BPR) Batang Kapas Pesisir Selatan.

\section{Proses promosi pada PT. Bank Pekreditan Rakyat (BPR) Batang Kapas Pesisir Selatan}

Aktivitas promosi pada PT. Bank Perkreditan Rakyat (BPR) Batang Kapas Pesisir Selatan lebih dominan menggunakan jenis Promosi Penjualan (Sales Promotion) merupakan kegiatan perusahaan untuk menjajakan produk yang dipasarkan sedemikian rupa, sehingga konsumen akan mudah melihatnya dan bahkan dengan cara penempatan dan pengaturan tertentu, maka produk tersebut akan menarik perhatian konsumen, promosi penjualan adalah insentif jangka pendek untuk mendorong pembelian atau penjualan dari sebuah produk atau jasa dengan tujuan, sebagai berikut:

a. Menarik para pembeli baru.

b. Memberi hadiah/penghargaan kepada konsumen-konsumen lama.

c. Meningkatkan daya pembelian ulang dari konsumen lama

d. menghindarkan konsumen berpindah ke merek lain.

e. mempopulerkan merek atau meningkatkan loyalitas kepada merek.

f. Meningkatkan volume penjualan jangka pendek dalam rangka meningkatkan pangsa pasar jangka panjang.

DanPenjualan Perorangan (Personal Selling) merupakan penyajian secara lisan oleh perusahaan kepada satu atau beberapa calon pembeli dengan tujuan agar barang atau jasa yang ditawarkan dapat terjual, sedangkan mengemukakan bahwa penjualan perorangan merupakan kegiatan perusahaan untuk melakukan kontak langsung dengan para calon konsumen dan diharapkan akan terjadi suatu hubungan atau interaksi positif antara pengusaha dengan para konsumennya.

PT. Bank Perkreditan Rakyat (BPR) Batang Kapas Pesisir Selatan hanya menggunakan dua jenis promosi untuk melakukan aktivitas untuk memperkenalkan atau mempromosikan produk tabungan dan deposito berjangka kepada kalangan masyarakat. Sedangkan pada landasan teori terdapat lima jenis-jenis promosi seperti :

1. Iklan (advertising)

Setiap bentuk persentasi yang berupa prmosi, gagasan barang atau jasa oleh sponsor yang telah ditentukan. Iklan berfungsi sebagai berikut,

(a) Informing, yaitu membuat calon nasabah menyadari tentang keberadaan sebuah produk baru. 
(b)Persuading, yaitu membujuk calon nasabah untuk menggunakan produk yang di iklankan.

(c) Reminding, yaitu mengingatkan kepada publik, agar publik tidak lupa dengan produk tersebut.

(d)Adding value, yaitu memunculkan kelebihan-kelebihan dari produk tersebut, shingga produk tersebut dapat menarik minat beli.

(e)Assing, periklanan dapat membantu pemasaran produk.

2. Promosi penjualan (sales promotion)

Merupakan kegiatan perusahaan untuk menjajakan produk yang diapsarkan sehingga konsumen akan mudah melihat dan bhkan untuk menarik perhatian calon nasabah.

3. Penjualan perorangan (personal selling)

Merupakan penyajian secara lisan oleh perusahaan kepada satu atau beberapa calon nasabah dengan tujuan agar jasa dapat terjual.

4. Hubungan masyarakat (public relations)

Merupakan berbagai program dirancang untuk mempromosikan atau melindungi citra perusahaan atau masing-masing produk.

5. Pemasaran lansung (direct marketing)

Merupakan sistem pemasaran interaktif yang menggunakan sebagai media komunikasi misalnya, katalog, pos, telepon, tv, mesin fax, internet, dll.

Maka diantara lima jenis-jenis promosi ini hanya dua yang digunakan oleh PT. Bank Perkreditan Rakyat (BPR) Batang Kapas Pesisir Selatan yaitu Promosi penjualan (sales promotion) dan penjualan perorangan (personal selling).

Mungkin akan lebih baik jika PT. Bank Perkreditan Rakyat (BPR) Batang Kapas Pesisir Selatan melakukan promosi yang lain seperti, mengik lankan produk, melakukan hubungan masyarat (public relation), dan pemasaran lansung (direct marketing), sebagai bentuk membuat calon nasabah menyadari dan mengetahui tentang keberadaan sebuah produk pada PT. Bank Perkreditan Rakyat (BPR) Batang Kapas Pesisir Selatan dan menjajakan produk tabungan dan deposito yang dipasarkan sedemikian rupa kepada kalangan masyarakat umum.

PT. Bank Perkreditan Rakyat (BPR) Batang Kapas Pesisir Selatan selalu berusaha semaksimal mungkin meyakinkan calon nasabahnya untuk menarik minat mereka terhadap produk-produk yang dimilikinya, agar para calon nasabah mau berkontribusi nantinya dan para calon nasabah mau menyimpan uang mereka pada PT. Bank Perkreditan Rakyat (BPR) Batang Kapas Pesisir Selatan, baik itu dalam bentuk tabungan maupun berupa deposito sehingga tujuan dari dilakukannya aktivitas promosi tersebut bisa tercapai. 


\section{SIMPULAN}

Berdasarkan uraian pada bab-bab sebelumnya, maka dapat diambil kesimpulan sebagai berikut :

1. Untuk melakukan aktivitas promosi dalam meningkatkan dana pihak ketiga PT. Bank Perkreditan Rakyat (BPR) Batang Kapas Pesisir Selatan telah melakukan promosi penjualan (sales promotion) dan penjualan perorangan (personal selling) seperti memberi hadiah kepada nasabah lama guna menghindari nasabah berpindah ke bank lain.

2. Aktivitas promosi yang dilakukan terdapat penurunan pada jumlah rekening deposito 2014 karena aktivitas promosi hanya ditargetkan kepada beberapa orang atau orang tertentu saja. Dan pada jumlah rekening tabungan terjadi peningkatan karena adanya tami bajapuik yang dilakukan oleh PT. Bank Perkreditan Rakyat (BPR) Batang Kapas Pesisir Selatan.

3. Dari hasil penelitian yang telah dilakukan PT. Bank Perkreditan Rakyat (BPR) Batang Kapas Pesisir Selatan belum sepenuhnya menerapkan aktivitas promosi seperti produk tabungan tami dan puro nagari.

\section{UCAPAN TERIMAKASIH}

Dengan menyebut nama Allah SWT yang Maha Pengasih lagi Maha Penyayang, penulis ucapkan puji dan syukur atas kehadirat-Nya, yang telah melimpahkan rahmat, hidayahNya kepada saya.penulis ingin menyampaikan terima kasih yang tak terhingga atas bimbingan bapak Doni Marlius SE,MM yang telah memberikan motivasi, masukan-masukan maupun kritik-kritik dan dukungan secara moril ataupun material dan untuk sahabat terbaik terimaksih untuk semangat dan dukungannya yang sangat berguna untuk Tugas Akhir. Akhir kata penulis ucapkan terimah kasih, semoga apa yang penils tuangkan dalam karya kecil ini memberikan manfaat terutama bagi saya sendiri selaku penulis. Amin ya Rabbal'alamin 


\section{DAFTAR PUSTAKA}

Adhaghassani, S. F. (2016). Strategi Bauran Pemasaran (Marketing Mix) 7P (Product, Price, Place, Promotion, People, Process, Physical Evidence di Cherryka Bakery). Pendidikan Teknik Boga, (Marketing Mix), 1-10.

Delsy, S. R. E. (2014). Pengaruh Dana Pihak Ketiga, Non Performing Loan Dan Capital. E-Jurnal Ekonomi dan Bisnis Universitas Udayana 3.11, 11, 650-673.

Denny, D. (2013). Promosi Dan Kualitas Layanan Pengaruhnya Terhadap Keputusan Konsumen Menggunakan Jasa Pembiayaan Pada Pt. Bess Finance Manado. Issn, $1(4), 51-59$.

Didik, D. (2013). Pengaruh Promosi Penjualan Terhadap Penjualan (Studi Kasus PT . Astra Internasional Tbk-TSO Cabang Soetoyo Malang ). Jurnal Administrasi Bisnis (JAB), 2(1), 21-28.

Febrianto, M. R. (2014). Pengaruh Produk, Harga, Tempat Dan Promosi Terhadap Perilaku Hedonis Pembeli Smartphone Samsung. Jurnal Ilmu \& Riset Manajemen.

Fianda, G. (2014). Pengaruh Struktur Organisasi terhadap Efektivitas Organisasi (Studi Pada Persepsi Pegawai Tetap Kantor Perwakilan Bank Indonesia Kediri). Jurnal Administrasi Bisnis (JAB), 7(2), 1-10.

Herri. (2008). Studi Peningkatan Peran Bank Perkreditan Rakyat (BPR) Dalam Pembiayaan Usaha Mikro Kecil (UMK) Di Sumatera Barat. Jurnal CBR UNAND BPR, 1-37.

Ika, W. (2015). Analisis Peranan Perkembangan Jumlah Giro, Deposito Dan Tabungan Masyarakat Terhadap Perkembangan Jumlah Sertifikat Bank Indonesia (Studi Kasus Pada Bank BCA). Jurnal Ekonomidan Bisnis GROWTH, 13(1), 95-113.

Irawan, A. (2014). Terhadap Keputusan Memilih Program Studi ( Studi pada Jurusan Akuntansi dan Jurusan Administrasi Bisnis di Politeknik Negeri Banjarmasin ). Jurnal Wawasan Manajemen, 2, 155-170.

Jack, F. A. (2012). Pengaruh Pemahaman Struktur Organisasi Terhadap Pencapaian Visi ( Studi Kasus Pada Pegawai Bidang Penganggaran ). Jurnal JEMI, 3(1), 1-10.

Kaharu, D., \& Budiarti, A. (2016). Pengaruh Gaya Hidup, Promosi, dan Kualitas Produk terhadap Keputusan Pembelian pada Cosmic. Jurnal Ilmu dan Riset Manajemen, ISSN : 2461-0593, 5(3), 1-24.

Kusnandar Bpr, B. (2013). Tinjauan HukumTerhadap pemberian kredit Oleh Bank 
Perkreditan (BPR) Berkaitan Dengan Jaminan. jurnal Ilmiah “advokasi,”'1(2), 5767.

Melnia, G. (2015). a Nalisis Pengaruh Tingkat Suku Bunga Dan Roa Terhadap Jumlah Dana Deposito. Jurnal Ilmiah Akuntansi Bisnis \& Keuangan (JIABK), 3(2), 43-51.

Metia, W. M. (2014). Pengalihan Tugas Pengaturan Dan Pengawasan Perbankan Dari Bank Indonesia Kepada Otoritas Jasa Keuangan Berdasarkan Undang-undang Nomor 21 Tahun 2011 Tentang Otoritas Jasa Keuangan. Jurnal Ekonomi, 22(2), 93-109.

Mongi, L. (2013). Kualitas Produk, Strategi Promosi Dan Harga Pengaruhnya Terhadap Keputusan Pembelian Kartu Simpati Telkomsel Di Kota Manado. Journal EMBA, 1(18), 2336-2346.

Nurfaizah. (2013). Pengaruh tingkat suku bunga deposito terhadap jumlah dana deposito pada bank mandiri cabang utama makassar. Jurnal akuntansi, 2(3).

Pebriani, U. (2017). Pengaruh Transaksi Electronic Banking Terhadap Fee Based Income pada PT. Bank CIMB Niaga, Tbk. Jurnal Keuangan dan Perbankan (JKP), 1(3), 187-194.

Radix, S. (2010). Partisipant, Process , dan Physical Evidence ) terhadap Keputusan Pembelian Produk Klinik Kecantikan Teta di Surabaya. jurnal Mitra Ekonomi dan Manajemen Bisnis, 1(2), 216-228.

Rahmadhani, L. (2011). Analisis Pengaruh CAR, Pertumbuhan DPK, Pertumbuhan Simpanan dari Bank Lain dan Suku Bunga SBI Terhadap Pertumbuhan Kredit. Jurnal Administrasi dan Ekonomi, 1-25.

Rokhmi, S. (2014). Pengaruh Strategi Promosi Terhadap Penjualan Produk Di Pt . United Indo Surabaya. Jurnal Ilmu \& Riset Manajemen, 3. No.10(10), 1-19.

Senaen, L. F., \& Tumbuan. (2015). Pengaruh People, Proses, Dan Promosi Terhadap Keputusan Pembelian Mobil Toyota Pada PT. Hasjrat Abadi Manado. Jurnal EMBA, 3(1), 345-356.

Sukma, Y. L. (2013). Pengaruh Dana Pihak Ketiga, Kecukupan Modal Dan Risiko Kredit Terhadap Profitabilitas (Perusahaan Perbankan yang Terdaftar di BEI). Jurnal Akuntansi, 1(2).

Sunardi, A. (2009). Aktivitas Bauran Komunikasi Pemasaran Di Perusahaan Jamu Ibu tjipto. Jurnal komunikator.

Susan, P. (2014). Pengaruh Dana Pihak Ketiga , Capital Adequacy Ratio , Return on 
Asset , Net Interest Margin dan Non Performing Loan Terhadap Penyaluran Kredit Bank Umum di Indonesia. E-Journal Management UMY, 5(2), 192-208.

Tatiek, N. (2007). Peran struktur organisasi dan sistem remunerasi dalam meningkatkan kinerja. Jurnal Ekonomi Bisnis, 14(2), 1-16.

Undang-undang RI Nomor 10. (1998). Undang-Undang Republik Indonesia Nomor 10 Tahun 1998 Tentang Perubahan Atas Undang-Undang Nomor 7 Tahun 1992 Tentang Perbankan. Www.Hukumonline.Com, 1-29.

Vera, P. K. (2015). Tabungan Dan Variabel Ekonomi Makro Yang Mempengaruhinya Dikota Ambon. jurnal ekonomi, IX(1), 95-100.

Yuniati, T. (2015). Pengaruh Bauran Pemasaran Terhadap Keputusan Konsumen Membeli Kartu Prabayar IM3 (Studi Kasus Pada Mahasiswa Stiesia Surabaya) Dyah Rizky Anggaryani. Jurnal Ilmu \& Riset Manajemen, 4(November). 